\title{
Educational practices of nursing in the puerperium: social representations of puerperal mothers
}

A prática educativa realizada pela enfermagem no puerpério: representações sociais de puérperas

La práctica educativa realizada por la enfermería en el puerperio: representaciones sociales de puérperas

\section{Hilana Dayana Dodou', Tamires Daianny Araújo de Oliveira', Mônica Oliveira Batista Oriá', Dafne Paiva Rodrigues", Patrícia Neyva da Costa Pinheiro', Izaildo Tavares Luna'}

' Universidade Federal do Ceará, Postgraduate Program in Nursing. Fortaleza, Ceará, Brazil.

"Universidade Estadual do Ceará, Postgraduate Program in Nursing and Clinical Health Care. Fortaleza, Ceará, Brazil.

\section{How to cite this article:}

Dodou HD, Oliveira TDA, Oriá MOB, Rodrigues DP, Pinheiro PNC, Luna IT. Educational practices of nursing in the puerperium: social representations of puerperal mothers. Rev Bras Enferm [Internet]. 2017;70(6):1250-8.

DOI: http://dx.doi.org/10.1590/0034-7167-2016-0136

Submission: 04-27-2016 Approval: 02-12-2017

\begin{abstract}
Objective: To understand the social representations of puerperal women regarding the contents of the educational practices carried out by nursing in the puerperium. Method: Descriptive and qualitative study, carried out from June to September 2014, in Fortaleza, Ceará State, Brazil. Nineteen puerperal women were administered a semi-structured interview. The Theory of Social Representations was used as a theoretical reference. Lexical analysis was performed with ALCESTE (version 2012) software. Results: The contents of the representations on educational practice were associated to the nursing team's orientations, with emphasis on breastfeeding and nursing. A lack of educational action regarding self-care of the puerperal woman was also revealed. Final considerations: It is necessary to redirect educational practices in the puerperium, in order to cover the biopsychosocial needs of women in this period of life. The educational actions should be based on the problematizing model, with a stimulus for the autonomy of puerperal mothers and valorization of their social knowledge.
\end{abstract}

Descriptors: Health Education; Postpartum Period; Nursing; Breastfeeding; Women's Health.

\section{RESUMO}

Objetivo: Apreender as representações sociais de puérperas sobre os conteúdos da prática educativa realizada pela enfermagem no puerpério. Método: Estudo descritivo e qualitativo, realizado de junho a setembro de 2014, em Fortaleza/CE, com 19 puérperas, por meio de entrevista semiestruturada. Utilizou-se a Teoria das Representações Sociais como referencial teórico; e o método de análise lexical usado foi o software ALCESTE - versão 2012. Resultados: Os conteúdos das representações acerca da prática educativa denotam que ela está associada às orientações da equipe de enfermagem, com ênfase principalmente na amamentação e alimentação da nutriz. Evidenciou-se também a carência de ações educativas acerca do autocuidado da puérpera. Considerações finais: É necessário reorientar as práticas educativas no puerpério, para que possam contemplar as necessidades biopsicossociais da mulher nesse período da vida. As ações educativas devem ser pautadas no modelo problematizador, com estímulo à autonomia da puérpera e valorização do seu saber social.

Descritores: Educação em Saúde; Período Pós-Parto; Enfermagem; Aleitamento Materno; Saúde da Mulher.

\section{RESUMEN}

Objetivo: Asimilar las representaciones sociales de puérperas sobre los contenidos de la práctica educativa realizada por la enfermería en el puerperio. Método: Estudio descriptivo y cualitativo, realizado de junio a septiembre de 2014, en Fortaleza/ CE, con 19 puérperas, por medio de entrevista semi estructurada. Se utilizó la Teoría de las Representaciones Sociales como referencial teórico; y el método de análisis lexical usado fue osoftware ALCESTE - versión 2012. Resultados: Los contenidos de las representaciones acerca de la práctica educativa denotan que ella está asociada a las orientaciones del equipo de enfermería, con énfasis principalmente al amamantamiento y alimentación de la nutriz. Se evidenció también la carencia de acciones educativas 
acerca del auto cuidado de la puérpera. Consideraciones finales: Es necesario reorientar las prácticas educativas en el puerperio, para que puedan contemplar las necesidades biopsicosociales de la mujer en ese período de la vida. Las acciones educativas deben ser basadas en el modelo problematizador, con estímulo a la autonomía de la puérpera y valoración de su saber social.

Descriptores: Educación en Salud; Período Post Parto; Enfermería; Lactancia Materna; Salud de la Mujer.

CORRESPONDING AUTHORＨilana Dayana DodouＥ-mail: hilanadayana@yahoo.com.br

\section{INTRODUCTION}

Health education constitutes an empowerment strategy in nursing care for women undergoing the puerperium, since it is able to promote the adoption of important and beneficial measures for maternal and child health ${ }^{(1)}$. Educational action is a guiding axis for nursing in the various fields of practice, especially in primary health care services $^{(2)}$. Thus, Nursing should develop educational programs that do not translate into a simple information transfer, but which are characterized as a practice articulated to the demands of puerperal women and their socio-cultural reality ${ }^{(3)}$. Nursing must associate health education with providing care, through horizontalalization. It is important that the nurse performs the role of caregiver and educator, by sharing knowledge and work, while aggregating popular know-how and avoiding traditional and authoritarian education ${ }^{(4)}$.

In this sense, the nursing care in the obstetrics scenario is configured as a space for the construction of knowledge from educational practices. This is in line with the guidelines of various public health policies, such as the National Humanization Policy and the National Policy for the Integral Attention to Women's Health (PNAISM) ${ }^{(3)}$.

These policies emphasize the need for health education throughout the pregnancy-puerperal cycle, since it is a time replete with changes in women's lives. This education should be guided by the principle of humanization and should aim at improving the level of information women have in relation to the body and health conditions, thereby increasing their capacity to make appropriate choices in this context and moment of their life. A major achievement in this area was the implementation of the PNAISM, which proposes comprehensive assistance to women's health based on an expanded perception of their life context ${ }^{(5)}$.

Regarding the National Policy of Health Promotion, health education is seen as a learning attitude based on problematizing, dialogic, emancipatory and critical pedagogical processes. These processes favor an increased critical-reflexive capacity and improvement in individual and collective skills to strengthen sustainable human development ${ }^{(6)}$. In this context, it can be seen that health education must be present in the nursing programs developed in the puerperium, in order to facilitate the incorporation of ideas and practices into people's daily lives and thereby meet their real needs and contribute to health promotion.

This health education must be conceived by a critical approach, which stimulates reflection and action among individuals, which enables them to learn and constitutes a cultural, political and social action. It must be permeated by a dialogical process that seeks continuous development and respect for the singularities of all the subjects involved. For this, it is necessary to break with the authoritarian behavioral patterns of professionals and recognize that health educators must be open to others in knowledge building ${ }^{(7)}$.

Thus, it is essential that the nurse recognizes the reality of puerperal mothers, together with the knowledge and care practices in the puerperium and can effectively carry out the teaching-learning process through knowledge and previous experiences of puerperal mothers, so that they truly feel they are being supported ${ }^{(8)}$. When considering people as holders of their own knowledge, which is constructed and shared socially, health education must also be seen through the meanings from their social perspective ${ }^{(9)}$. Since women experience educational practices throughout the pregnancy-puerperal cycle, health education becomes an object of great relevance for this group, which can provoke social representations.

It is these representations that guide the individual's actions in their reality, particularly the action of women experiencing puerperium, based on a system of values defined under social influence. It is practical wisdom, because: it is socially elaborated; it is determined by the subject; by the social, cultural and ideological system in which she is inserted; and by the nature of the relations that she maintains with this social system; and serves as a guide to social groups ${ }^{(9)}$.

Thus, in order for health professionals, especially nursing professionals, to be able to carry out effective and integral educational practices in the care of puerperal women, it is necessary that they value the social knowledge shared by these subjects and seek to understand their interpretations and meanings in this object. Consequently, the study objective was to understand the social representations of puerperal women about the contents of the educational practice provided by the nursing team during puerperium.

\section{METHOD}

\section{Ethical aspects}

The research was initiated only after approval by the Research Ethics Committee of the State University of Ceará. All ethical and legal precepts have been respected in accordance with Resolution No. 466/12, which regulates research with human beings ${ }^{(10)}$.

\section{Theoretical-methodological framework}

This study was based on the Theory of Social Representations (TRS), since the meanings, beliefs and knowledge of the puerperal participants of the study were valorized $^{(9)}$. 


\section{Type of study}

A descriptive study was performed with a qualitative approach.

\section{Methodological procedures}

\section{Study scenario}

The study was based on five Family Health Centers (FHSs) of the Regional Executive Secretariat (RES) IV in the city of Fortaleza, Ceará State. Brazil.

\section{Data source}

Participants in this study were 19 randomly selected puerperal mothers, who met the following inclusion criteria: they were registered in one of the units surveyed; in the late or remote puerperium phase; and age 18 years or over. The exclusion criteria were: women who left the FHS area of RES IV (due to change of address) during the period of information collection; and mothers with mental disorders or cognitive deficits, as identified during the initial contact with the participants. The theoretical saturation of data was used to define the set of participants in the study ${ }^{(11)}$.

\section{Data collection and organization}

Communication with the participants was established through visits made by the researcher to all five FHSs. The interaction with puerperal mothers occurred through a presentation by the researcher, with an explanation of the research and its objectives. In addition, these women were informed that the research would take place in their home environment. After clarification, their consent to participate in the research was requested and the researcher's visit to their home was scheduled, according to their convenience.

The information was collected from June to September 2014. The semi-structured interview was used to collect information and an instrument to trace the obstetric and sociodemographic profile of the participants. The interview script aimed to explore the significance attributed to educational practice in the postpartum period.

The interview was performed once only for each participant, through a home visit by the researcher and lasted on average 10 minutes. It was conducted solely by the principal researcher, who was coursing a master's degree at the time and had experience in research into women's health due to her participation in the Women's Health and Nursing Research Group (GRUPESME) at the State University of Ceará, Brazil.

Some family members were present at the time of the survey but these were requested to respect the privacy of the woman and not to interrupt the interview. The annotations relevant to the research were carried out after the interview. The dialogues were recorded, transcribed in full and the transcript was not presented to study participants. The database was prepared and organized according to the lexical analysis method.

\section{Data analysis}

After organization of the database, it was processed in the software ALCESTE version 2012. ALCESTE employs Descending Hierarchical Classification analysis and enables lexical analysis of textual material, by offering lexical classes that are characterized according to the vocabulary and segments of texts that share this vocabulary ${ }^{(12)}$. To use this program, it is necessary to organize the corpus to be analyzed, which is formed by the units of initial contexts (ICUs), from which the program will compute the initial fragmentation, and in relation to this study corresponds to each interview ${ }^{(13)}$. After the program recognizes the indications of ICUs, it divides the material into elementary context units (ECUs), i.e. units with the smallest sense fragment, calculated by the program as a function of the corpus ${ }^{(12)}$.

This program groups the semantic roots of words and defines them by classes, taking into account the function of the word within a given text, categorizing them by content analysis. The program then gives the number of classes resulting from the analysis, the reduced forms of the words, the semantic context and the ECUs characteristic of each class ${ }^{(14)}$. Based on this material, the researcher determined the content present therein, naming each class from the information provided by the program.

In addition, the software provides the Phi coefficient, which is an association coefficient that measures the link between a word and its class of appearance. The higher the Phi, the more relevant the word is for constructing the class. The participants' statements are identified according to the ICU number of which they were part, that is, according to the number of their interview and the corresponding ECU.

From the information processing in Alceste, the ECUs were allocated into classes, comprising the results of a larger study. In this study, the contents of the Class "health education in the puerperal period" were analyzed and discussed, since this is the object selected for discussion. The interpretation and analysis of the classes was based on the Theory of Social Representations perspective. The COREQ (Consolidated Criteria for Reporting Qualitative Research) protocol was used to improve the presentation of the results from this research.

\section{RESULTS}

The obstetric and sociodemographic profile of the participants shows mainly multiparous women, aged between 18 and 25 years. Of these eight were married, 13 had completed high school, and 11 did no paid work.

Next, the information that emerged from analysis of the class in question was presented, it was formed by 26 ECUs and 43 analyzable words. In terms of ECU aggregation, the statistical significance was $10 \%$ of the total ECUs analyzed.

The program considered for all classes only the words with Phi equal to or greater than 0.16 as to be the more representative words, i.e. only these words were considered relevant for the given class. The most representative words were: soda; explained; milk; breastfeeding; months; breast; give; advised; milk teeth; relationship; feeding; suckle; first; baby; causes; said; wanted; and fruit juice.

These words express the guidelines received by puerperal women during the postpartum period. From the words of greater association with this class and the ECUs it can be observed that the teaching is focused primarily on exclusive breastfeeding up to six months of life and on nutritional care for the puerperal as a nursing mother. 
The statements by puerperal mothers emphasize that counseling by the nursing team was focused primarily on the issue of breastfeeding. The benefits of exclusive breastfeeding are highlighted from the perspective of a child's healthy development:

They spoke about the importance of the baby being immune, it is good when they are teething, and for health, for me to do everything to give up to six months. (ecu $\mathrm{n}^{\circ} 260$ icu $\left.\mathrm{n}^{\circ} 13\right)$

They only taught how to breastfeed. It helped, helped position on the breast. The health of the baby, even in the matter when it begins teething, it is a healthy food that comes from the mother. (ecu $\mathrm{n}^{\circ} 299$ icu $\mathrm{n}^{\circ} 15$ )

They said that the child was going to be healthier, until the sixth month it was complete nutrition, she did not need even water, both for her and for me. (ecu $n^{\circ} 370$ icu $\left.n^{\circ} 1\right)$

The puerperal mothers reported the help received by the nursing team to breastfeed, emphasizing that the professionals contributed with this practice through support and massage to avoid breast engorgement and facilitate descent of the milk:

They helped because my breasts were always very hard and it hurt a lot, then they would come, they taught me to massage to be able to release the milk. (ecu $\mathrm{n}^{\circ} 170$ icu $\mathrm{n}^{\circ} 7$ )

In the following statement, the puerperal mother emphasizes that she attended an educational lecture about breastfeeding where she received help from the maternity nursing team on how to breastfeed:

In the first months I attended a lecture on breastfeeding, there I learned from this lecture. Then in the maternity they would always look, seeing if she was suckling right, if she was getting the breast. (ecu $\mathrm{n}^{\circ} 190$ icu $\left.\mathrm{n}^{\circ} 8\right)$

The above statement shows that the breastfeeding instructions started from the first months of gestation through an educational lecture attended in the prenatal period, which reinforces the importance of the educational process throughout the pregnancy-puerperal cycle so that it can have real significance to the puerperal woman and influence her care.

In the following report, the puerperal woman emphasizes that her postpartum period was relatively easy and associates this with the support she received from family and health professionals; thereby emphasizing the importance of the breastfeeding course to gain experience and knowledge to perform breastfeeding:

I liked it, it was cool, I was given attention by my husband, my family, from the professionals, and nothing was missing. Everything they told me to do, I did. I breastfed, all right. I did the breastfeeding course in the maternity, the first daughter we did not have much experience, so I did the course, which helped me a lot. (ecu $n^{\circ} 352$ icu $\left.n^{\circ} 19\right)$

The primiparous mothers reported having received instructions on how to breastfeed (correct suckling by the baby and its position during breastfeeding) from the nursing staff and from their relatives, as can be seen in the excerpts below:

They talked about how to breastfeed her. For her to breastfeed better, when she opened her mouth I placed the areola of the breast in her mouth, because it is very good, I did not know anything. (ecu $\mathrm{n}^{\circ} 185$ icu $\mathrm{n}^{\circ} 4$ )

From my mother, because I trusted her. She explained everything I had to know, that I could not lift weight, could not bend down, taught me even how to hold her and offer her the breast, because at first she did not take my breast. (ecu $n^{\circ} 92$ icu $n^{\circ} 5$ )

Another recommendation emphasized in the postpartum period was breast care: the puerperal mothers were instructed to perform pumping to facilitate the milk descent, to take sunbaths to avoid fissures, as well as to perform cleaning of the breast. This is demonstrated in the following reports, reinforcing that the nursing guidance was mostly focused on aspects related to breastfeeding:

They said to always sunbathe, when about to breastfeed always wash the breast and take care of it properly. These things, feeding, give nothing but milk. (ecu $n^{\circ} 167$ icu $\left.n^{\circ} 3\right)$

They said that we had to wash our breasts, we had to expose them to the sun, to massage to facilitate the descent of the milk. (ecu ${ }^{\circ} 241$ icu $n^{\circ} 12$ )

In addition, it was found in this class that the health education carried out in the puerperal period addressed nursing care, in addition to breastfeeding. The feeding guidelines were emphasized in the perspective of successful breastfeeding; the puerperal mothers were instructed in relation to care with their own alimentation in order to increase their milk production and to promote the health of the child, as can be seen in these reports:

Drink lots of liquids, fruit juice, because you could give more milk. They said that the child would grow stronger and breastfeed until the six months, because it is good for her and the milk teeth. (ecu $n^{\circ} 189$ icu $\left.n^{\circ} 10\right)$

There was a nurse who came to be able to discharge from hospital and directed me to bathe, to feed, not to eat fatty food, not to drink soda, to drink fruit juice to create more milk, to always look for healthy food so that milk can progress and continue to breastfeed. (ecu $n^{\circ} 282$ icu $n^{\circ} 14$ )

Through the educational guidelines, the mothers understood that the use of certain artificial foods with caffeinebased products, such as coffee, soda and chocolate, should be avoided during breastfeeding, since they may cause colic and alter the child's intestinal function. This can be seen in the following statements:

And the food, I did not eat what could be passed on to him, it was soda, chocolate and all what was said that can give the child colic. (ecu $n^{\circ} 271$ icu $\left.n^{\circ} 16\right)$ 
She explained all this to me and other things that people talk about, from the old days, that it is what not to eat because of the child, that she will have stomach ache, cannot eat chocolate, drink soda, which cause gas and colic in the child. (ecu $\mathrm{n}^{\circ} 93$ icu ${ }^{\circ}{ }^{6}$ )

The puerperal mothers also reported not having received guidance regarding self-care, only in relation to the child, reinforcing that the focus of health education practiced by postpartum professionals was focused on child-care strategies.

As for me, I do not remember. They always talked about the baby, but not about me. Do not take soda, these things, avoid snacks so as not to hurt the breast so much, and for me not to get fat. (ecu $\mathrm{n}^{\circ} 169$ icu $\left.\mathrm{n}^{\circ} 7\right)$

The accompaniment I had was only for the child, in relation to me, like an orientation, a professional to guide you, there was none, do you understand? (ecu $n^{\circ} 287$ icu $\left.n^{\circ} 14\right)$

Reports from postpartum women show dissatisfaction with the lack of follow-up in the late and remote puerperium and by primary care professionals, and consequently the lack of educational programs and guidelines that could help them to undergo this period:

I think it is harmful, it was for them to come, give me support, guidance, because a first-time mother does not have much experience, she needs experience, to guide them how to do it and how not to. (ecu n²6 icu n²)

A visit from a professional would be nice to give more information because we are not very sure if we are looking after ourselves in the right way, if we are taking the right care with the baby. (ecu $\mathrm{n}^{\circ} 332$ icu $\mathrm{n}^{\circ} 17$ )

After I left the maternity ward, I received no further guidance. I missed it yes, because I think it's important to have a follow-up for you and your child during such a delicate period. (ecu $\mathrm{n}^{\circ} 372$ icu $\mathrm{n}^{\circ}$ 9)

\section{DISCUSSION}

In this study, the practice of health education in the puerperium was associated to the orientations received from the nursing team, focusing mainly on issues and aspects related to breastfeeding.

In the reports of puerperal mothers, it was shown that they were advised on the benefits of exclusive breastfeeding and that breastmilk was associated with the words "immune", "healthy food", "complete food" and "baby health". This is due to the guidelines received by the nursing team, which emphasize that the practice of breastfeeding should be exclusive up to six months, since milk is considered the healthiest food for the child, will protect against illness and contribute to the development of teeth ${ }^{(15)}$. These women consider breastfeeding in the common sense view that health is simply absence of disease and that human milk protects against disease ${ }^{(16)}$.

The mothers interviewed represented breastfeeding as important for the healthy growth and development of the child.
These women have access to the reified universe of scientific knowledge that is shared and disseminated at the moment of meetings with health professionals and other peers in their group, through media campaigns on breastfeeding and their previous experiences; then incorporating this technical discourse to their knowledge and guiding themselves by $\mathrm{it}^{(9)}$.

This study revealed that most of the reports on breastfeeding indicated the child as the sole benefiter from the act of breastfeeding, thereby disregarding the psychosocial advantages of this practice for the mother-child binomial. This demonstrates that breastfeeding is still seen from a biological perspective, without appreciating the sociocultural factors that influence it, consequently it is necessary to rethink these still dominant technical discourses on health ${ }^{(17)}$. The guidelines for health professionals should also include the benefits of breastfeeding for the lactating mother, since this practice also has benefits for maternal health ${ }^{(18)}$.

In this study, the primiparous women also emphasized the help received by the nursing team to breastfeed, and that this was characterized by the support, continuous follow-up, teaching and practical help to perform massage. The way health professionals approach breastfeeding with puerperal women, when performed in an effective manner, contributes to exclusive breastfeeding, especially when technologies are added. Therefore, the use of light and light-hard technologies in promoting breastfeeding is important, using relationships (bonding, welcoming, listening, counseling) and knowledge structured in the care of the mother-child binomial and in the educational process, with a view to providing the support and guidance necessary for successful breastfeeding ${ }^{(18)}$

Thus, the establishment of human relationships is fundamental for the promotion of breastfeeding. Women's counseling and skin-to-skin contact between mother and baby are the key light technologies that should be encouraged. In order to determine the needs of women in relation to breastfeeding and to promote personalized care, light-weight technologies such as the Breastfeeding Self-Efficacy Scale can be used, in its full or short form, both of which have already been adapted to the Brazilian context ${ }^{(19-20)}$.

Regarding the health education model, it was found that lectures and courses were indicated as some of the teaching methods used by nursing, and although the puerperal mothers reported that they learned from these modalities, it is important that the nursing team is careful using these educational practices, since they are related to the traditional model of health education, characterized mainly by the attempt to merely change behavior. It is essential that health education does not occur in a unidirectional and authoritarian way, via the simple transfer of information from those who hold the knowledge to those who need the knowledge and are passive learners ${ }^{(21)}$.

It is necessary for educational practice to be linked to the needs of puerperal mothers and their reality, valuing their knowledge and using approaches that respect women as autonomous and responsible for their health, in order to seek the shared construction of knowledge.

Thus, the educational process must permeate the entire pregnancy-puerperal cycle so that the woman is prepared from the beginning of gestation as to the care she should take with both 
her own and the baby's health. It is important that the information be worked in a diluted form and according to the moment the woman is experiencing, using participatory methodologies that strengthen the participation, reflection, criticality and empowerment of the subjects ${ }^{(22)}$.

The mothers of this study reported that they received support from the health professionals for breastfeeding, which is an instrumental support, since it includes practical help, transmission of knowledge and encouragement for the practice of breastfeeding.

Some research has shown that although it may vary according to the sociocultural context and the level of development of the country in which women are inserted, interventions to promote breastfeeding, which include support for breastfeeding and health education, are effective in increasing indices and duration of breastfeeding. When these interventions are performed in prenatal and puerperium, their effect is longer lasting, accruing benefits from breastfeeding up to six months of age ${ }^{(23-24)}$.

In view of this, it is evident that educational action is a strategy to promote breastfeeding; nevertheless, these programs are often carried out in a unidirectional form, without valorizing the woman as protagonist in this process, or her prior knowledge. Therefore, it is necessary to find ways to involve all subjects participating in strategies to promote breastfeeding to take into account their culture, habits and beliefs ${ }^{(22)}$.

This study also showed that the puerperal mothers were guided by the professionals in the joint lodging and their family as to the correct handling of the breast and position of the baby during breastfeeding. These teachings contribute to the success of this practice and to the prevention of complications such as mastitis and engorgement, which may negatively affect the breastfeeding event ${ }^{(15)}$. The orientation and help provided by the puerperal woman's mother was also fundamental to successful breastfeeding, since the woman trusts the knowledge that is disseminated by her relatives and uses this to guide her caregiving.

Thus, the social support network in which the family is inserted is also considered to be an opportunity for educational actions, since it is a source of support and exchange of knowledge, influencing the mother's decisions in the breastfeeding process ${ }^{(25)}$.

Another prominent orientation in the reports of puerperal mothers was breast care, including sunbathing, cleaning and pumping, to avoid complications such as engorgement. Guidance and support from the health team are fundamental to avoid problems and favor successful breastfeeding. These are light technologies that are easy to perform in clinical practice, yet can contribute to the maintenance of this activity ${ }^{(15,26)}$.

In view of the above, in this class, it was shown that health education in the postpartum period prioritized nursing care, since breastfeeding is something that can only be performed by the mother and represents the survival and health of the child. A "milk tyranny" is observed, with the idea that the mother needs to sacrifice herself and, if she does not breastfeed, she is not a good mother. The woman is on the margins of this care, of this learning, as if, after the birth of the child, she ceases to exist as a woman, becoming solely a mother ${ }^{(2)}$.

Besides breastfeeding, another issue addressed in the educational practice carried out in the puerperium was nutrition for the lactating mother. However, the feeding guidelines focused on the success of breastfeeding, valuing the benefits of adequate milk production and child health, without emphasizing the benefits of correct feeding behavior for women's health.

According to the reports, the puerperal mothers believed that their diet affects breastfeeding. In the consensual universe of these women, a healthy diet, based on natural foods such as fruit and vegetables, and increased fluid intake are indispensable for the production of strong and healthy milk, thereby contributing to the development and health of the child(27). Among the benefits of regular postnatal feeding are: avoiding maternal fragility during breastfeeding, strengthening breastmilk, and benefiting the baby with healthier food. This issue has been widely discussed with women since pregnancy, when they receive guidance from their families and professionals about foods that should be avoided and those that bring benefits to the woman herself ${ }^{(28)}$.

It was observed in the statements of puerperal mothers the representation that eating affects breastfeeding. These externalized representations in women's discourses reveal a comprehending of aspects of the scientific content on breastfeeding; it consists, therefore, in scientific rationality reinterpreted in the light of common-sense knowledge $\mathrm{e}^{(9)}$.

It was observed that the puerperal woman's social knowledge together with cultural aspects that involve breastfeeding modify the alimentary intake of the woman in this period of their life. In this sense, maternal self-care aims at the wellbeing of the newborn, such that restriction of artificial foods aims to prevent colic in the child ${ }^{(27)}$.

The lactating mother's diet presents foods that need to have their consumption moderated or even avoided, these include: foods that are hot, spoilt, acidic, sour, fatty, or sweet, and also the drinking of alcoholic beverages, coffee, soda, and others. These should be avoided, since when consumed they can cause discomfort in the child and especially abdominal pain ${ }^{(28)}$.

In this study, it was possible to demonstrate that the dietary habits of women during breastfeeding are part of a social system full of meanings, so that foods are surrounded by associations that social knowledge attributes to them. In this way, the lactating woman's eating habits have a strong significance for herself and her peers; the woman is obliged to have a healthy diet, since her eating habits have a strong association with the health and well-being of the child.

This common sense knowledge about feeding in the puerperium, despite differing from scientific models, is not devoid of logic, since it is based on the observations and experiences of people within their social group, and this wealth must be considered, since it has value for the subjects and serves as a guide for their behavior ${ }^{(9)}$.

Under this logic, it is of the utmost importance that professionals value common-sense knowledge and seek to be aware of the setting in which these women live as well as their eating habits during the puerperium; only in this way can popular knowledge be included in health education planning in order to counsel puerperal mothers without devaluing their habits and beliefs, in order to optimize their programs and achieve greater acceptance of the guidelines. 
For this, it is essential that health education is based on participative action that stimulates reflection, involves listening and mutual respect among all those involved. It is necessary to value people's knowledge and experiences through dialogue, problematization and ethics to identify the opinions, feelings and impressions of social actors ${ }^{(7,25)}$.

Moreover, in this study, the dissatisfaction of some puerperal women was also observed due to the lack of educational activities in the late and remote puerperium by primary care professionals. This indicates that it is necessary to rethink educational practice developed at this level of care, since it comprises an important scenario for postpartum health promotion.

Some puerperal women voiced dissatisfaction with the care received during the puerperal period, due to a lack of attention from the health team to their needs, besides a lack of guidelines for their self-care. This demonstrates that health education in this period focused on the child by concentrating on guidelines for breastfeeding and feeding ${ }^{(15)}$. Therefore health professionals should include in their care necessary guidance not only for the child, but also to bring together their universe of relationships, by considering the family and child as a single client. From this conduct, providing care will be centered on humanization and ensure the woman and her family feel welcomed and valorized ${ }^{(29)}$.

\section{Study limitations}

This study presents some limitations, since it is restricted to a specific geographical region, so the results found should not be generalized. Nevertheless, they can be analyzed as a basis for the practice of health education performed by nurses and other health professionals in the puerperal period. Another limitation of the study was investigation only of the meanings attributed by puerperal women to the postpartum educational practice, without exploring the social perspective of the other subjects involved in this process, notably health professionals and family members. There is also a need for: further studies on the educational practice of nursing in the postpartum period; and the development of studies that evaluate the impact of these practices on the behavior and health of the individuals involved.

\section{Contribution to Nursing, health and public policy}

This research has made it possible to unveil the understanding of women regarding educational practice in the postpartum period, thus pointing the way ahead in the search to improve and broaden educational practice of nursing in the puerperium. Thus, the focus should not be only the health of the child, but also highlight the self-care of puerperal mothers. In addition, it underscores the need to overcome the traditional model of health education that still predominates in the professional practice of nurses and other health professionals.

\section{FINAL CONSIDERATIONS}

The contents of the social representations of puerperal women demonstrate that health education was associated with the nursing team's guidelines in the postpartum period. This study contributed to increase the knowledge in the nursing area, by showing the puerperal women's representations about the educational practice carried out by nursing, which focused primarily on the child and guidance related to breastfeeding and nursing.

Another important aspect was the lack of educational programs addressing self-care in the immediate and late postpartum puerperium, which caused dissatisfaction, since at this stage the woman needs guidance and support to perform her self-care. It was observed that the mother was left at the margin of learning, since the main focus of the orientation was on the health of the child, which denotes the necessity for reflection and change in this field and in professional practice, since health education is one of the main devices for health promotion.

In view of this, it is necessary to encourage the adoption of new proposals for health education in the context of the puerperium that value the development of autonomy among women to act as a protagonist in the decisions that involve their health.

This study contributes to nursing, insofar as it demonstrates the need to reorient educational practices developed with puerperal women in order to contemplate all their needs in this period of life. This emphasis should not only be on biological aspects, but also directed to the biological. psychological and sociocultural aspects since these factors permeate the experiences of this period.

It is necessary to redefine the educational actions in the postpartum period, so that they are based on the problematizing model, which stimulates reflection and action of the subjects, using dialogic, emancipatory and critical processes that favor autonomy and participation of all involved. It is necessary to promote a change in the pedagogical logic, expanding the strategies for groups and other educational spaces that favor the interaction between puerperal mothers and health professionals, in the construction and collective sharing of knowledge.

Nurses should be open to the needs of puerperal women to build knowledge, and their educational practice should value the social knowledge of these women, so that their actions in the puerperium contribute to health promotion in the motherchild binomial.

\section{REFERENCES}

1. Busanello J, Lunardi Filho WD, Kerber NPC, Lunardi VL, Santos SS. Participação da mulher no processo decisório no ciclo gravídico-puerperal: revisão integrativa do cuidado de enfermagem. Rev Gaúcha Enferm [Internet]. 2011[cited 2016 Oct 15];32(4):807-14. Available from: http://www.scielo.br/pdf/rgenf/v32n4/v32n4a23.pdf

2. Guerreiro EM, Rodrigues DP, Silveira MAM, Lucena NBF. [Prenatal care in primary care under the health of pregnant women and nurses]. Rev Min Enferm [Internet]. 2012[cited 2016 Oct 15];16(3):315-23. Available from: http://reme.org.br/artigo/detalhes/533 Portuguese 
3. Guerreiro EM, Rodrigues DP, Queiroz ABA, Ferreira MA. [Health education in pregnancy and postpartum: meanings attributed by puerperal women]. Rev Bras Enferm[Internet]. 2014[cited 2016 Oct 15];67(1):13-21. Available from: http://www.scielo.br/pdf/ reben/v67n1/0034-7167-reben-67-01-0013.pdf Portuguese

4. Progianti JM, Costa RF. [Educational practices developed by nurses: reflections on women's pregnancy and labor experiences]. Rev Bras Enferm[Internet]. 2012[cited 2016 Oct 15];65(2):257-63. Available from: http://www.scielo.br/pdf/reben/v65n2/v65n2a09. pdf Portuguese

5. Rodrigues DP, Guerreiro EM, Ferreira MA, Queiroz ABA, Barbosa DFC, Fialho AVM. Social representations of women in pregnancy, postpartum, and educational actions. Online Braz J Nurs[Internet]. 2013[cited 2016 Oct 15];12(4):911-22. Available from: http://www.objnursing.uff.br/index.php/nursing/article/viewFile/4287/pdf_37

6. Brasil. Ministério da Saúde. Secretaria de Vigilância em Saúde. Política Nacional de Promoção da Saúde: PNaPS. Revisão da Portaria MS/GM nº 687, de 30 de março de 2006 [Internet]. Brasília; 2014 [cited 2016 Oct 15]. Available from: http://bvsms. saude.gov.br/bvs/publicacoes/pnps_revisao_portaria_687.pdf

7. Freire P. Pedagogia do oprimido. Rio de Janeiro: Paz e Terra; 2011.

8. Bernardi MC, Carraro TE, Sebold LF. Visita domiciliária puerperal como estratégia de cuidado de enfermagem na atenção básica: revisão integrativa. Rev Rene[Internet]. 2011[cited 2016 Oct 15];12(esp):1074-80. Available from: http://www.revistarene.ufc.br/ vol12n4_esp_html_site/a25v12espn4.html

9. Moscovici S. Representações sociais: investigações em psicologia social. 10. ed. Petrópolis: Vozes; 2013.

10. Brasil. Ministério da Saúde. Conselho Nacional de Saúde. Resolução no 466, de 12 de dezembro de 2012. Dispõe sobre as pesquisas envolvendo seres humanos [Internet]. Brasília; 2012 [cited 2016 Oct 15]. Available from: http://conselho.saude.gov.br/ resolucoes/2012/Reso466.pdf

11. Fontanella BJB, Lucheri BM, Saidel MGB, Ricas J, Turato ER. [Sampling in qualitative research: a proposal for procedures to detect theoretical saturation]. Cad Saúde Pública[Internet]. 2011[cited 2016 Oct 15];27(2):389-94. Available from: http://www.scielo. $\mathrm{br} / \mathrm{pdf} / \mathrm{csp} / \mathrm{v} 27 \mathrm{n} 2 / 20 . p d f$ Portuguese

12. Camargo BV. Alceste: um programa informático de análise quantitativa de dados textuais. In: Moreira ASP, Jesuino JC, Nóbrega SM. Perspectivas teórico-metodológicas em representações sociais. João Pessoa: Ed. Universitária UFPB; 2005.p. 511-539.

13. Azevedo DM, Miranda FAN. Teoria das representações sociais e ALCESTE: contribuições teórico-metodológicas na pesquisa qualitativa. Saúde Transf Soc Health Soc Change[Internet]. 2012[cited 2016 Oct 15];3(4):4-10. Available from: http://incubadora. periodicos.ufsc.br/index.php/saudeetransformacao/article/view/1588/2235

14. Azevedo DM, Costa RKS, Miranda FAN. Uso do ALCESTE na análise de dados qualitativos: contribuições na pesquisa em enfermagem. Rev Enferm UFPE[Internet]. 2013[cited 2016 Oct 15]; 7(Esp):5015-22. Available from: http://www.revista.ufpe.br/ revistaenfermagem/index.php/revista/article/download/3297/6801

15. Rodrigues DP, Dodou HD, Lago PN, Mesquita NS, Melo LPT, Souza ASS. Care for both mother and child immediately after childbirth: a descriptive study. Online Braz J Nursing[Internet]. 2014[cited 2016 Oct 15];13(2):227-38. Available from: http:// www.objnursing.uff.br/index.php/nursing/article/view/4231/pdf_140

16. Osório $\mathrm{CM}$, Queiroz ABA. Social representations concerning the breastfeeding practices of women from three generations. Esc Anna Nery Rev Enferm[Internet]. 2007[cited 2016 Oct 15];11(2):261-67. Available from: http://www.scielo.br/pdf/tce/v22n2/ en_v22n2a20.pdf

17. Junges CF, Ressel LB, Budó MLD, Padoin SMM, Hoffmann IC, Sehnem GD. Percepções de puérperas quanto aos fatores que influenciam o aleitamento materno. Rev Gaúcha Enferm[Internet]. 2010[cited 2016 Oct 15];31(2):343-50. Available from: http:// www.scielo.br/pdf/rgenf/v31n2/20.pdf

18. Silva NM, Waterkemper R, Silva EF, Cordova FP, Bonilha ALL. Conhecimento de puérperas sobre amamentação exclusiva. Rev Bras Enferm[Internet]. 2014[cited 2016 Oct 15];67(2):290-95. Available from: http://www.scielo.br/pdf/reben/v67n2/0034-7167reben-67-02-0290.pdf

19. Oriá MOB, Ximenes LB. Translation and cultural adaptation of the Breastfeeding Self-Efficacy Scale to Portuguese. Acta Paul Enferm[Internet]. 2010[cited 2016 Oct 15];23(1):230-38. Available from: http://www2.unifesp.br/acta/pdf/v23/n2/ v23n2a13 en.pdf

20. Dodt RCM, Ximenes LB, Almeida PC, Oriá MOB, Dennis CL. Psychometric and maternal sociodemographic assessment of the breastfeeding self-efficacy scale: short form in a brazilian sample. J Nurs Educ Pract[Internet]. 2012[cited 2016 Oct 15];2(3):6673. Available from: http://sciedu.ca/journal/index.php/jnep/article/download/627/553

21. Alves GG, Aerts D. As práticas educativas em saúde e a Estratégia Saúde da Família. Ciênc Saúde Colet[Internet]. 2011 [cited 2016 Oct 15];16(1):319-25. Available from: http://www.scielo.br/pdf/csc/v16n1/v16n1a34.pdf

22. Linhares FMP, Pontes CM, Osorio MM. Construtos teóricos de Paulo Freire norteando as estratégias de promoção à amamentação. Rev Bras Saúde Matern Infant[Internet]. 2014[cited 2016 Oct 15];14(4):433-39. Available from: http://www.scielo.br/pdf/rbsmi/ v14n4/1519-3829-rbsmi-14-04-0433.pdf

23. Imdad A, Yakoob MY, Bhutta ZA. Effect of breastfeeding promotion interventions on breastfeeding rates, with special focus on developing countries. BMC Public Health[Internet]. 2011[cited 2016 Oct 15];11(Suppl 3):S24. Available from: https:// 
bmcpublichealth.biomedcentral.com/articles/10.1186/1471-2458-11-S3-S24

24. Haroon S, Das JK, Salam RA, Imdad A, Bhutta ZA. Breastfeeding promotion interventions and breastfeeding practices: a systematic review. BMC Public Health[Internet]. 2012[cited 2016 Oct 15];13(Suppl3):S20. Available from: https://bmcpublichealth. biomedcentral.com/articles/10.1186/1471-2458-13-S3-S20

25. Linhares FMP, Pontes CM, Osório MM. Breastfeeding promotion and support strategies based on Paulo Freire's epistemological categories. Rev Nutr[Internet]. 2013[cited 2016 Oct 15];26(2):125-34. Available from: http://www.scielo.br/pdf/rn/v26n2/ a01v26n2.pdf

26. Fonseca-Machado MO, Haas VJ, Stefanello J, Nakano AMS, Gomes-Sponholz F. Breastfeeding: knowledge and practice. Rev Esc Enferm USP[Internet]. 2012[cited 2016 Oct 15];46(4):809-15. Available from: http://www.scielo.br/pdf/reeusp/v46n4/en_04.pdf

27. Acosta DF, Gomes VLO, Kerber NPC, Costa CFS. The effects, beliefs and practices of puerperal women's self-care. Rev Esc Enferm USP[Internet]. 2012[cited 2016 Oct 15];46(6):1327-33. Available from: http://www.scielo.br/pdf/reeusp/v46n6/en_07.pdf

28. Marques ES, Cotta RMM, Botelho MIV, Franceschini SCC, Araújo RMA. Representações sociais sobre a alimentação da nutriz. Ciênc Saúde Colet[Internet]. 2011[cited 2016 Oct 15];16(10):4267-4. Available from: http://www.scielo.br/pdf/csc/v16n10/ a32v16n10.pdf

29. Botêlho SM, Boery RNSO, Vilela ABA, Santos WS, Pinto LS, Ribeiro VM, et al. Maternal care of the premature child: a study of the social representations. Rev Esc Enferm USP[Internet]. 2012[cited 2016 Oct 15];46(4):929-34. Available from: http://www.scielo. $\mathrm{br} / \mathrm{pdf} /$ reeusp/v46n4/en_21.pdf 